\title{
ANTI-ADENOVIRUS ACTIVITY OF THE MEDICAL INTRANAZAL DRUG NAZOFERON
}

\author{
O.Yu. Povnitsa ${ }^{1}$, L.O. Biliavska ${ }^{1}$, Yu.B. Pankivska ${ }^{1}$, \\ S.D. Zagorodnya ${ }^{1}$, M.I. Borshchevskaya ${ }^{2}$ \\ ${ }^{1}$ Zabolotny Institute of Microbiology and Virology, NAS of Ukraine, \\ 154 Acad. Zabolotny Str., Kyiv, 03143, Ukraine \\ 2 JSC "Farmak", 63 Kyrylivska Str., Kyiv, 04080, Ukraine \\ e-mail:povnitsa@ukr.net
}

\begin{abstract}
Currently, 90 different types of human adenoviruses (HAdV) are known, which have been classified into seven species from $A$ to $G$ and new adenovirus types continue to emerge. Antigenic diversity of viruses inhibits the process of creating universal vaccines and causes the development of resistance to direct-acting antiviral drugs. In addition to the rapid development of drug resistance, too narrow a range of existing drugs and a significant number of side effects limits the treatment of adenoviral infections. There is currently no specific etiotropic antiviral drug. Therefore, the development of new effective drugs and the selection of the optimal drug for the treatment of infections caused by adenoviruses remain relevant. The aim of the study was to investigate the antiviral properties of the drugs Nazoferon spray and Nazoferon drops in a model of human adenovirus serotype 3. Methods. Determination of cytotoxicity and antiviral action of drugs was performed by standard colorimetric method using MTT. The titer of the virus, synthesized in the presence of drugs was determined by the end point of dilution of the virus, which causes $50 \%$ development of the cytopathic effect of the virus on cells (CPE). Results. Low cytotoxicity of Nazoferon spray and Nazoferon drops (manufactured by JSC "Farmak", Ukraine) was shown, $C C_{50}$ is $53854 \mathrm{IU} / \mathrm{ml}$ and $54357 \mathrm{IU} / \mathrm{ml}$, respectively. Quantitative and qualitative composition of excipients had no cytotoxic effect. In prophylactic regimens, interferon preparations did not inhibit the reproduction of adenovirus in vitro. Taking into account that most of the virions remain associated with the cells during the reproduction of adenovirus in the cell, we used test to determine infectivity lysates of infected and treated cells. The infectious titer of the synthesized HAdV3 was reduced by $3.2 \log _{10}$ and $3.7 \log _{10}$ for Nazoferon spray and drops, respectively. Conclusions. Nazoferon spray and drops can be recommended as anti-adenoviral drugs that block the reproduction of adenovirus, and due to their bioavailability and low cost have significant advantages in the treatment of acute respiratory infections (ARIs) caused by human adenoviruses.
\end{abstract}

Keywords: human adenoviruses, Nazoferon spray and drops, alpha-2-b recombinant human interferon.

Acute respiratory viral infections (ARIs) are a serious public health problem and occupy a leading position in human infectious diseases. Among the most common are influenza viruses, adenoviruses, respiratory syncytial virus, parainfluenza viruses, rhino- and coronaviruses $[1,2]$. The proportion of adenoviral infection is up to $40 \%$. By the age of 5 , almost all children have adenoviral infection at least once [3, 4], it is spread in closed groups: kindergartens, schools and among servicemen, known outbreaks of hospital adenoviral infection. With increasing age, the range of SARS narrows to three epidemiologically relevant viral infections influenza caused by influenza A virus, adenoviral diseases caused by adenoviruses 3, 4 and 7 serotypes and rhinovirus infections [5]. Human adenoviruses 3, 4 and 7 serotypes cause acute diseases of the upper and lower respiratory tract and eyes. They are often the cause of severe conjunctivitis, keratoconjunctivitis, pneumonia, bronchitis in patients with chronic diseases. Serotype 3 adenovirus is also associated with mesenteric adenitis and intestinal intussusception. In newborns with chronic diseases cardiovascular and pulmonary systems, adenoviruses can cause severe, often fatal, multiorgan processes [6-9]. Along with airborne, fecal-oral, contact routes of infection are possible. Susceptibility to adenoviruses is common. They can cause both sporadic cases and epidemic outbreaks. Affected 
people are able to spread adenoviruses for up to 40 days and be a source of infection for others [7]. Against the background of infection, chronic pathology is more often exacerbated and systemic, allergic and autoimmune diseases, as well as some types of malignant processes are manifested [8]. Adenoviruses have the ability to latently persist, while not being recognized by the macroorganism. This allows them to escape the effects of the immune system and reactivate under favorable conditions. Adenoviruses, along with Epstein-Barr virus (EBV), cytomegalovirus (CMV) and human herpes virus type 6 are among the most dangerous agents that can be fatal in immunocompromised patients [1,9-11]. Adenovirus infection remains highly relevant due to circulation throughout the year [9]. The importance of diseases caused by adenoviruses in organ transplantation is growing, when latent viral infection, in the absence of specific etiotropic drugs, leads to a huge number of deaths. There is currently no specific etiotropic antiviral drug [11-13].

The aim of the study was to investigate the antiviral properties of the drugs Nazoferon spray and Nazoferon drops on the model of human adenovirus 3 (HAdV3).

Materials and methods. Culture of Hep- 2 cells of epithelioid origin of human laryngeal carcinoma, obtained from the collection of the R.E. Kavetsky Institute of Experimental Pathology, Oncology and Radiobiology of the National Academy of Sciences of Ukraine was used in the studies. Cells were grown in plastic vials (Thermo Fisher Scientific, USA) in a nutrient medium consisting of $45 \%$ of DMEM (Sigma, USA), $45 \%$ of RPMI 1640 (Sigma, USA) and $10 \%$ of calf embryo serum inactivated by heating at $56{ }^{\circ} \mathrm{C}$ (Sigma, USA), antibiotic $-40 \mu \mathrm{g} / \mathrm{ml}$ of gentamicin. The reference strain of serotype 3 adenovirus (HAdV3) was obtained from the collection of the Institute of Influenza of the Russian Academy of Medical Sciences. The virus was cultured in Hep-2 cells, stored in aliquots as a suspension of infected cells in growth medium at $-70^{\circ} \mathrm{C}$. A pool of adenovirus with a titer of $1.6 \times 10^{7} \mathrm{IFU} / \mathrm{ml}$ (inclusion of forming units $/ \mathrm{ml}$ ) was used.

Drugs: Nazoferon nasal spray $100000 \mathrm{IU} / \mathrm{ml}$, series 130919 , specific activity $111.464 \%$ and Nazoferon nasal drops $100000 \mathrm{IU} / \mathrm{ml}$, series 100919, specific activity $112.56 \%$ manufactured by JSC "Farmak", Ukraine.
Determination of cytotoxic effects of drugs was performed by standard colorimetric method using 3-(4,5-dimethylthiazol-2-yl)-2,5-diphenyl tetrazolium bromide (MTT) [14] as decreasing of cell metabolic activity. The optical density of the samples was determined at a wavelength of $538 \mathrm{~nm}$ using a Multiscan FC reader (ThermoFisherScientific, USA). The obtained optical densities of the test sample were compared with the optical density of cell control without the addition of drugs, and the formula calculated the percentage of viable, metabolically active cells under different concentrations of drugs:

\section{$\%$ of viable cells $=(\mathrm{A} \times 100 / \mathrm{B})$,}

where $\mathrm{A}$ is the average optical density of test samples for a given concentration of drugs, B - the average value of the optical density of cell control samples. The concentration of drugs that inhibits cell viability, determinated as metabolic activity, by $50 \%\left(\mathrm{CC}_{50}\right)$ was calculated compared to cell control.

Determination of antiviral activity of drugs using MTT analysis (by changes in the metabolism of infected cells) [15]. The following schemes of drug administration were used: 1) 24 hours before infection of cells with the virus, 2) immediately after adsorption of the virus. After a 1-day of cell growth in 96-well plates (Sarstedt, Germany), and formation of $90 \%$ of the monolayer, the growth medium was removed. According to scheme 1 , different concentrations of drugs were used ( $200 \mu 1 /$ well), and according to scheme 2 - virus in volume $50 \mu 1 /$ well, the multiplicity of infection was determined in advance (multiplicity of infection, MOI $=40-90$ IFU/cells). After $24 \mathrm{~h}$ of contact of cells with different concentrations of drugs (according to scheme 1), the cells were infected by removing the medium and adding $50 \mu \mathrm{l} /$ well of virus. After $2 \mathrm{~h}$ of adsorption, the non-adsorbed virus was removed from all treatment regimens, the cells were washed with Hanks' solution (Sigma, USA) and $200 \mu 1$ of support medium (scheme 1) or medium containing preparations in different concentrations (scheme 2) was added, and plates were incubated at $37{ }^{\circ} \mathrm{C}$ in an atmosphere of $5 \%$ $\mathrm{CO}_{2}$ for 3 days. Next, $20 \mu \mathrm{l} /$ well of MTT solution (Sigma, USA) with a concentration of $5 \mathrm{mg} / \mathrm{ml}$ was added to the wells. The plates were incubated at $37^{\circ} \mathrm{C}$ in an atmosphere of $5 \% \mathrm{CO}_{2}$ for 3 hours, the solution was removed and $100 \mu \mathrm{l} /$ well of $96 \%$ ethanol was added. After shaking the plates for 10 minutes, the optical density in the wells was determined. The percentage of protection against 
the virus was calculated by the formula [15]:

(ODexp.) - (ODcv) / (ODcc) - (ODcv) x 100 \%,

where: ODexp. - the average value of the optical density in the wells with the drug, ODcv - the average value of the optical density of virus control, ODcc - the average value of the optical density of cell control. Cytodestruction, monolayer destruction, and inhibition of cell metabolism were observed in virus control.

The titer of the virus synthesized in the presence of drugs was determined by the cytopathic effect (CPE) of the virus on cells in the end point of dilution, which causes $50 \%$ cell damage. Cytodestruction of cells, destruction of the monolayer and inhibition of cell metabolism were detected after 5 days of culturing the cells with the virus. The materials were collected, frozen three times, thawed, centrifuged for $20 \mathrm{~min}$ at $3,000 \mathrm{rpm}$, the cell pellets were removed, serial 10 -fold dilutions of virus-containing material were prepared, and the Hep-2 cells were infected. After 5 days of culturing the cells, MTT solution was added to the plates, the optical densities of the samples were determined and the infectious titer of the virus was calculated. Dilution of the virus, which reduces the optical density of the sample compared to the optical density of cell control by $50 \%$, is the titer of the virus, and is expressed in $\mathrm{TCD}_{50} / \mathrm{ml}$ (tissue cytopathogenic dose of the virus). The reduction in virus yield in the presence of drugs was determined by the formula [16]:

$\%=($ titer CV-titer D) / titer CV*100,

where: CV - titer of virus control; D - titer of the test sample.

Statistical processing of results. All studies were performed in three experiments; the number of parallel determinations was 3-4. Mean values, standard deviation, and mean error were calculated. Differences in averages were considered significant at $p \leq 0.05$. The research results were processed using Microsoft Office Excel 2010.

Results. The first step in the study of substances is the assessment of their toxicity to cell culture, so we studied the cytotoxic effects of Nazoferon spray and Nazoferon drops in Hep-2 cells. As can be seen from Figure 1, Nazoferon spray at a concentration of $100000 \mathrm{IU} / \mathrm{ml}$ inhibited cell viability by $71 \%$, and Nazoferon drops at a concentration of 100000 $\mathrm{IU} / \mathrm{ml}$ - by $77 \%$. With decreasing concentration of drugs, their toxicity decreased significantly. Using Microsoft Excel and trend lines, $\mathrm{CC}_{50}$ values were determined for Nazoferon spray and Nazoferon drops, which were $53854 \mathrm{IU} / \mathrm{ml}$ and $54357 \mathrm{IU} / \mathrm{ml}$, respectively.

In antiviral activity studies, 2 multiple infections were used -40 and $90 \mathrm{IFU} / \mathrm{cell}$. It is shown that under the prophylactic scheme study (24 hours before infection), the metabolic activity of the cells did not change compared with the control of the virus. The effect did not depend on the concentration of drugs and the multiplicity of infection (not illustrated). Cytodestruction and a decrease in the metabolic activity of cells were observed in the viral control (Fig. 2). No manifestations of the antiviral action of the drugs were detected in the prophylactic regimen of drug administration. In the therapeutic regimen of drug administration (after the adsorption of the virus on the cells), less destruction of the cell monolayer and a decrease in the metabolic activity of cells were observed.

It is known, that during the reproduction of adenovirus in the cell, most of the virus remains associated with the cells. Therefore, we used test to determine infectivity of infected and treated cells lysates. To do this, Hep-2 cells were infected with ten-fold dilutions of lysates of infected cells (treated and untreated with drugs according to the treatment regimen) and the titer of the virus was determined. The drug Nazoferon spray only at a concentration of $50000 \mathrm{IU} / \mathrm{ml}$ inhibited the reproduction of adenovirus in Hep-2 cells. Thirty six percent of living cells were preserved by diluting the material in 10 times, and $74 \%$ - in 100 times. While in the control of the virus for breeding 10 times found $13 \%$ of living cells, 100 times $-17 \%$, and 1000 times $-62 \%$. Reducing the concentration of the Nazoferon spray to $10000-400 \mathrm{IU} / \mathrm{ml}$ led to a loss of anti-adenoviral action. Nazoferon drops inhibited the formation of adenovirus more effectively. If at a concentration of $50000 \mathrm{IU} / \mathrm{ml}$ the effectiveness of its action was similar to the effectiveness of the Nazoferon spray, then when the concentrations decreased, its effect was maintained, in contrast to the Nazoferon spray. Using the prediction function of Microsoft Excel 2010, we calculated the titers of adenovirus infectivity in the control and in the presence of different concentrations of drugs (Fig. 3).

The drug Nasoferon spray at a concentration of $50000 \mathrm{IU} / \mathrm{ml}$ reduced the titer of adenovirus by $3.2 \log _{10}$, which indicates its pronounced anti-adenoviral effect. At a concentration of $10000 \mathrm{IU} / \mathrm{ml}$, it inhibited adenovirus by only $0.6 \log _{10}$, and at lower concentrations slightly 
stimulated the reproduction of the virus. Nasoferon drops at a concentration of $50000 \mathrm{IU} / \mathrm{ml}$ reduced the infectious titer of the virus by $3.7 \log _{10}$, at concentrations of 10000 and $2000 \mathrm{IU} / \mathrm{ml}$ - by $2.8 \log _{10}$, and at a concentration of $400 \mathrm{IU} / \mathrm{ml}-$ by $2.7 \log _{10}$. However, Nazoferon spray and

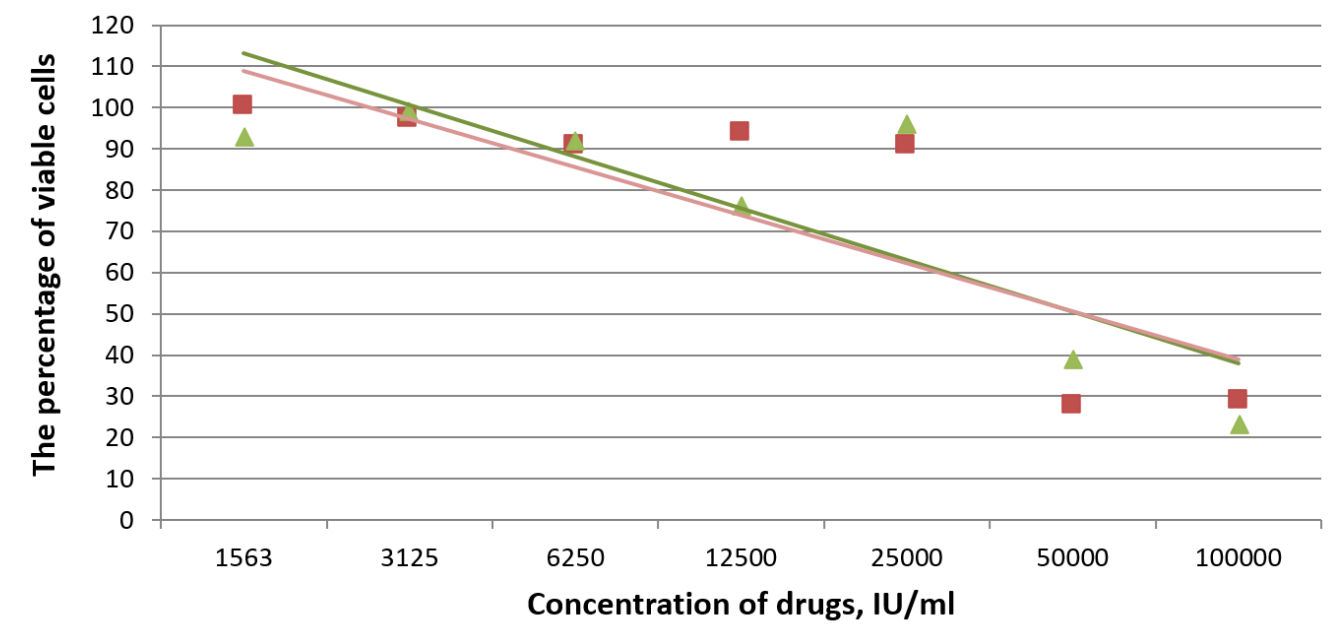

- nazoferon drops — nazoferon spray

F i g. 1. Determination of cytotoxic concentrations of Nazoferon spray and Nazoferon drops

A

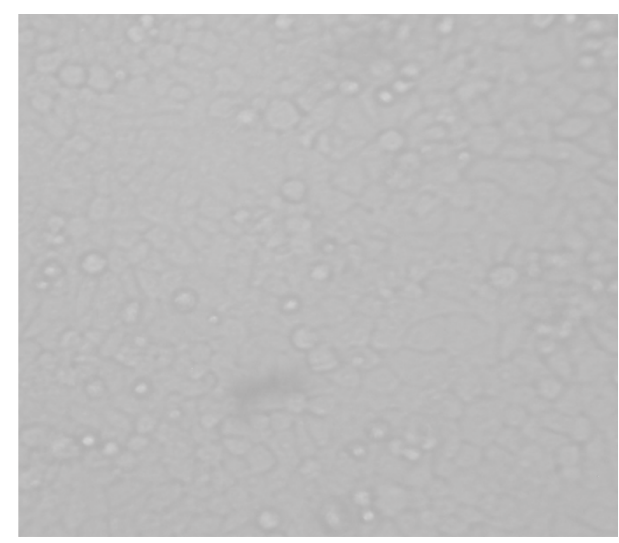

C

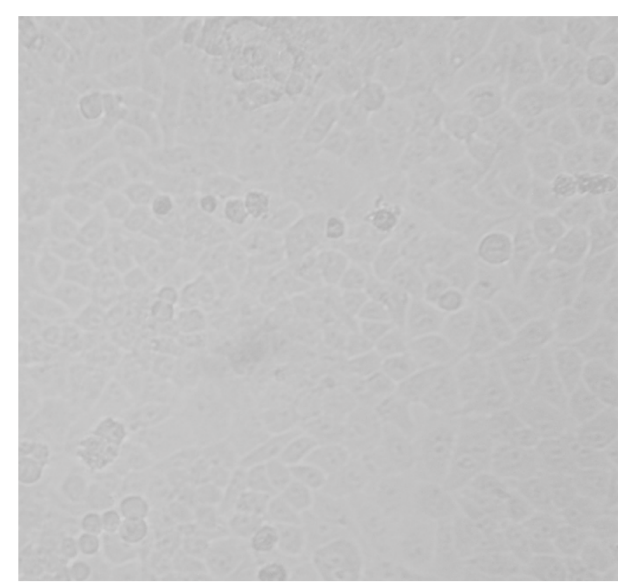

B

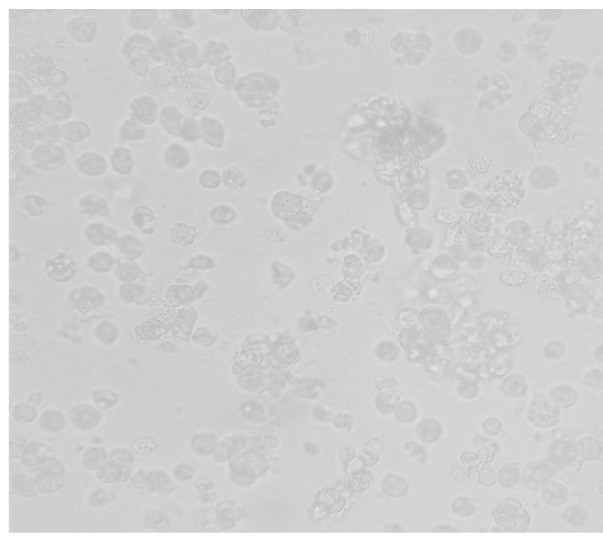

D

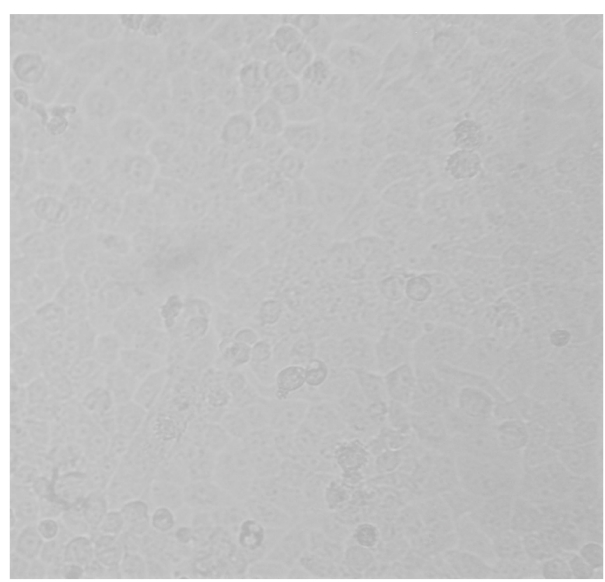

F i g. 2. The monolayer of Hep-2 cells: A) control of untreated cells; B) control of infected cells; C) infected cells treated with drug Nazoferon spray $50000 \mathrm{IU} / \mathrm{ml}$; D) infected cells treated with drug Nazoferon drops $50000 \mathrm{IU} / \mathrm{ml}$ 


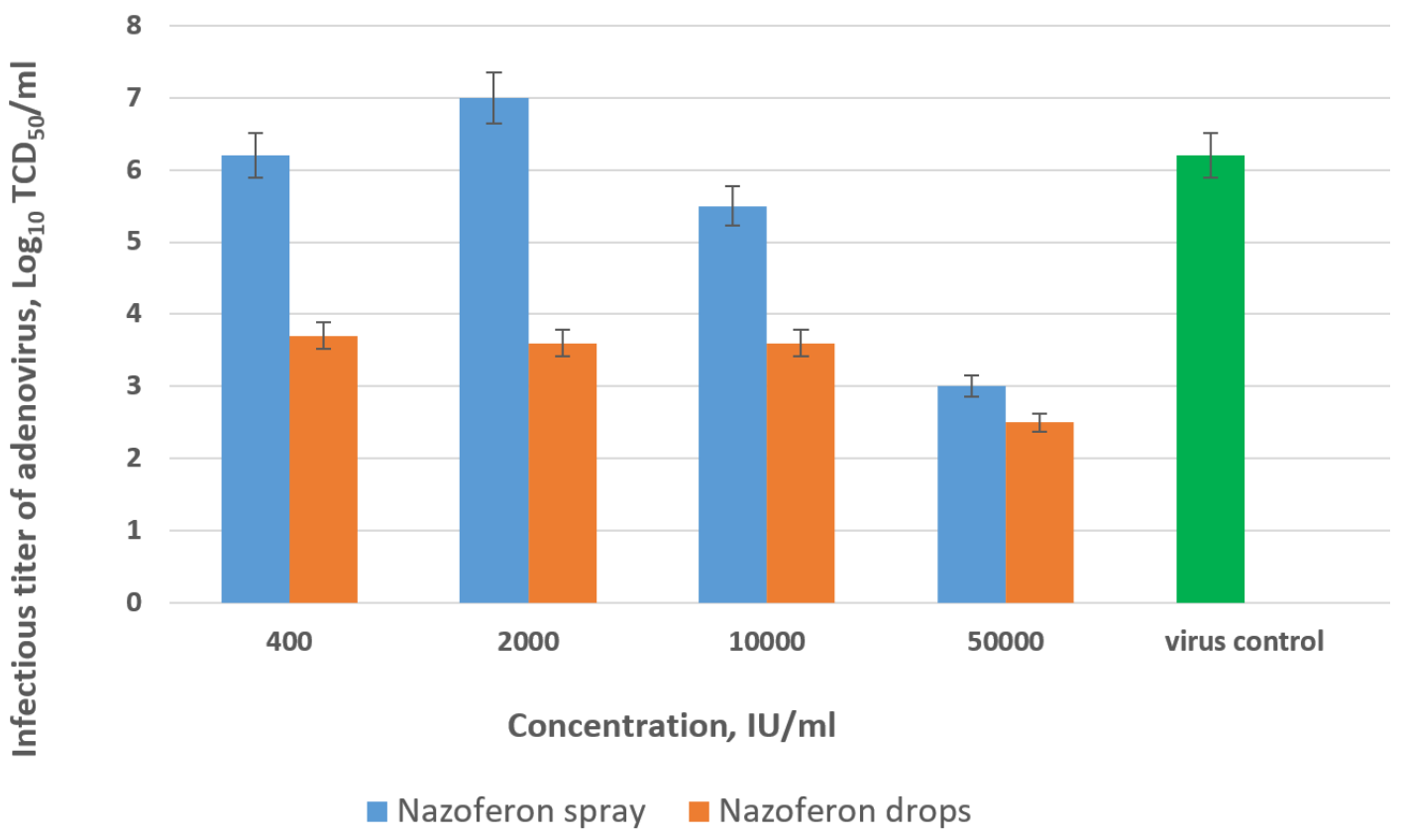

F i g. 3. The effect of the studied drugs on infectious titers of de novo synthesized HAdV3

Nazoferon drops have been shown to significantly reduce the infectivity of the newly synthesized virus by reducing the virus titer by more than $2 \log _{10}$, indicating their pronounced antiadenoviral activity [18].

Discussion. The problem of treatment of acute respiratory infections is the limited possibilities in the treatment of patients with SARS of noninfluenza etiology, primarily the treatment of adenoviral infections. There is currently no specific etiotropic drug $[12,13,17]$. The disadvantage of existing synthetic antiadenoviral drugs is their high toxicity, side effects and suppression of the immune system [1]. Adenovirus vaccines are not used due to their proven oncogenicity [19]. In vitro studies on models of different viruses have shown the antiviral effect of natural interferons, as well as immunoglobulin G [20]. In this regard, the use of drugs that activate non-specific immune response factors and thus increase the body's overall resistance may be appropriate for the treatment and prevention of SARS [20-22]. Drugs with immunomodulatory and so-called secondary antiviral action are widely studied [2, 7, 23-27]. The modern pharmaceutical market has dozens of dosage forms of interferons (IFN). In clinical practice, two main types of human IFN are used: type $1-$ IFN- $\alpha$ and $\beta$ and type $2-$ IFN- $\gamma$. The action of IFN is due to blocking the translation of viral mRNA by IFN-induced enzymes oligoadenylate synthetase, protein kinases and latent endonucleases. As a result, the translation of viral proteins is stopped and the reproduction of viruses is suppressed. This mechanism is universal and is implemented in many viral infections, which explains the wide range of clinical applications of IFN $[7,25]$. At the same time, there is a rather ambiguous assessment of the effect of natural interferons on the reproduction of adenoviruses. There are data on their resistance to alpha and beta interferons [26]. This is due to the synthesis of low molecular weight virus-associated RNA type I or the product of the early E1A gene of adenovirus, which inhibit IFN-induced kinase and interrupt the action of IFN [26, 27]. In the mid-1980s, pure homogeneous recombinant interferon alfa-2b (second-generation drugs), identical to natural interferon, was obtained by genetic engineering. Studies conducted in recent years confirm the effectiveness of recombinant interferon in the prevention and treatment of influenza and other respiratory infections of viral etiology [28-33]. The biological action of interferon alpha is characterized by universality and high activity against many DNA and RNA viruses, it is low toxic, hypoallergenic, it has no addictive effects. Today, various forms of interferon are available: oral, injectable, intranasal, etc. Analysis of the literature proves the feasibility of intranasal use of drugs. Nasal forms of IFN are available as a ready-to-use solution in a dropper 
or spray bottle, so the drugs are easy to use and have prospects for effective use in clinical practice [30-32].

Our results on the effect of Nazoferon (alpha-2b-recombinant human interferon) on the infectivity of adenovirus suggest that the drug inhibits the synthesis of viral proteins, possibly late, does not interfere with the manifestations of viral cytopathic action. The use of interferon $\alpha-2 b$ inhibits the synthesis of viral RNA and DNA due to inhibition of transcription and translation processes, activation of ribonuclease, which damages the matrix RNA of the virus and prevents the penetration of the virus into the cell $[30,33]$. The study of the infectivity of cell lysates, comparing the titers of the virus in the control and experiment, revealed a high antiviral effect of Nazoferon. The results of our study were confirmed in a publication in which the authors claim that interferon alpha does not directly block the interaction of viruses with cells, but affects their reproduction in the cell [33].

Thus, we show:

- Low cytotoxicity of Nazoferon spray and drops (manufactured by JSC "Farmak", Ukraine), $\mathrm{CC}_{50}$ is $53854 \mathrm{IU} / \mathrm{ml}$ and $54357 \mathrm{IU} / \mathrm{ml}$, respectively. Toxicity of Nazoferon spray and drops at a concentration of $100000 \mathrm{IU} / \mathrm{ml}$ may be due to the presence of excipients: trometamol, trometamol hydrochloride, hypromellose, disodium edetate, lysine hydrochloride, potassium chloride and methyl parahydroxybenzoate (E 218), which are part of the preparation.

- In prophylactic regimens, interferon preparations did not inhibit the reproduction of adenovirus in vitro.

- According to the therapeutic regimen of drugs administration (after adsorption of the virus on cells), slightly less destruction of the cell monolayer and metabolic activity of cells was observed.

- The study of the effect of drugs on infectious titers of synthesized de novo HAdV3 revealed that at a concentration of $50000 \mathrm{IU} / \mathrm{ml}$ Nazoferon spray and drops reduced the infectious titer of the virus by $3.2 \log _{10}$ and $3.7 \log _{10}$, respectively. The drug Nasoferon drops at concentrations of 10000 $400 \mathrm{IU} / \mathrm{ml}$ reduced the virus titer by $2.7 \log _{10}$.

- Differences in the antiviral activity of Nazoferon drops and spray, in our opinion, are associated with rosemary series of alpha- $2 b$ interferons with different specific activity used in the manufacture of drugs. The specific activity of interferons according to the requirements of AND can be from $80 \%$ to $125 \%$.
Conclusions. Nazoferon spray and drops can be recommended as anti-adenoviral drugs that block the reproduction of adenovirus, and due to their bioavailability and low cost have significant advantages in the treatment of ARI caused by human adenoviruses.

\section{ПРОТИАДЕНОВІРУСНА АКТИВНІСТЬ ЛІКАРСЬКОГО ІНТРАНАЗАЛЬНОГО ПРЕПАРАТУ НАЗОФЕРОН}

О.Ю. Повниця ${ }^{1}$, Л.О. Білявська ${ }^{1}$, Ю.Б. Паньківська, С.Д. Загородня ${ }^{1}$, M.I. Борщевська ${ }^{2}$

\author{
${ }^{I}$ Інститут мікробіології і вірусології \\ ім. Д.К. Заболотного НАН України, \\ вул. Академіка Заболотного, 154, \\ Київ, 03143, Украӥна \\ ${ }^{2} A T$ «Фармак», вул. Кирилівська, 63, \\ Київ, 04080, Украӥна
}

\section{Резюме}

Гострі респіраторні вірусні інфекції (ГРВІ) $є$ серйозною проблемою охорони здоров'я у всьому світі та займають провідне місце в інфекційній патології людини. Серед найбільш поширених віруси грипу, аденовіруси, респіраторно-синцитіальний вірус, віруси парагрипу, рино- та коронавіруси. Частка аденовірусної інфекції становить до $40 \%$. На сьогодні відомо 90 різних типів аденовірусів людини (HAdV), які були класифіковані на сім видів від А до G, і нові типи аденовірусу продовжують з'являтися. Антигенне різноманіття аденовірусів гальмує процес створення універсальних вакцин і викликає розвиток стійкості до противірусних препаратів прямої дії. Крім швидкого розвитку резистентності до лікарських засобів, лікування аденовірусних інфекцій обмежується занадто вузьким колом існуючих препаратів та значною кількістю побічних ефектів. В даний час немає специфічного етіотропного противірусного препарату. Тому розробка нових ефективних препаратів та підбір оптимального препарату для лікування інфекцій, викликаних аденовірусами, залишаються актуальними. Метою дослідження було вивчити противірусні властивості препаратів Назоферон спрей та Назоферон краплі на моделі аденовірусу людини 3 серотипу. Методи. Визначення цитотоксичності та противірусної дії лікарських засобів проводили стандартним ко- 
лориметричним методом з використанням МТT (за порівнянням метаболічної активності клітин за присутності препаратів та контролів клітин і вірусу). Вивчали цитотоксичну дію препаратів Назоферон спрей, Назоферон краплі в клітинах Нер-2. Для дослідження противірусної дії були використані 2 схеми введення лікарських засобів: за 24 години до зараження клітин вірусом та відразу після адсорбції вірусу. Титр вірусу, синтезований у присутності лікарських препаратів, визначався за кінцевою точкою розведення вірусу, що спричиняє 50 \% розвиток цитопатичної дії вірусу на клітини (ЦПД). Усі дослідження проводили в 3-х повторах, кількість паралельних визначень становила 3-4. Розраховували середні значення, стандартне відхилення, похибку середньої величини. Відмінності середніх показників вважали достовірними при $\mathrm{P}<0,05$. Обробку результатів досліджень проводили з використанням програми Microsoft Office Excel 2010. Результати. Показано низьку цитотоксичну дію спрею Назоферону та крапель Назоферону (виробництва ВАТ «Фармак», Україна), СС $_{50}$ становить 53854 MO/ мл та 54357 МО/мл відповідно. За профілактич-

1. Lion T. Adenovirus infections in immunocompetent and immunocompromised patients. Clinical Microbiology Reviews. 2014; 27(3):441-62.

2. Osidak L, Yanina M, Zarubayev V, Goncharova E, Alekseeva O. [Prevention of adenoviral infection in preschool institutions using the drug recombinant interferon $\alpha-2 \beta$ ]. Pediatric infections. 2016; 2:9-14. Russian.

3. Tatochenko VK. [Treatment of acute respiratory diseases in children]. The attending physician. 2005; 7. Russian.

4. Epiphanova NV, Navikova NA. [The role of adenoviruses in the occurrence of acute intestinal infection in children. Analytical Review] Medial. 2014; 2(12):45-57. Russian.

5. Lviv N, Pisareva M, Maltsev O. [Features of the etiological structure of SARS in certain age and occupational groups of the population of St. Petersburg in the epidemic season 2013-2014]. Journal of Infectious Diseases. 2014; 6(3):62-70. Russian.

6. Lviv N, Solomina A, Zhdanov K, Lobzin Y. [Features of the clinical course of acute respiratory ної схеми дослідження (внесення препаратів до клітин за 24 год до зараження) препарати інтерферону не гальмували розмноження аденовірусу in vitro. Для терапевтичної схеми введення препаратів (зразу після інфікування клітин вірусом) показана зміна метаболічної активності клітин у порівнянні з контролем вірусу, що свідчить про активність препаратів. Дослідженнями впливу препаратів на синтез інфекційного аденовірусу встановлено, що в концентрації 50000 МО/мл спрею та крапель Назоферону інфекційний титр вірусу знижувався відповідно на $3,2 \log _{10}$ та 3,7 log. Препарат Назоферон краплі в концентрації 10000-400 МО/мл знижував титр вірусу на $2,7 \log _{10}$. Висновки. Назоферон спрей та краплі можуть бути рекомендовані як протиаденовірусні препарати, що блокують розмноження аденовірусу, а завдяки їх високій біодоступності та низькій вартості мають значні переваги при лікуванні ГРЗ, спричинених аденовірусами людини.

Ключові слова: аденовіруси людини, антивірусні препарати, Назоферон краплі та спрей, рекомбінантний альфа-2-b інтерферон.

diseases caused by adenoviruses of epidemically significant serotypes]. Journal of Infectious Diseases. 2014; 6(2):5-11. Russian.

7. Baranaeva EA. [Acute respiratory viral infections in children: clinical features, modern possibilities of prevention and treatment]. Medical News. 2015; 12:7-10. Russian.

8. Yulish E. [Antiviral therapy in the treatment of acute respiratory diseases in children]. Modern Pediatrics. 2013; 5(53):75-79. Russian.

9. Tram T, Burchette JL, Hale LP. Fatal Dessiminated Adenovirus Infection in Immunocompromised Patients. American Journal of Clinical Pathology, $2003 ; 120: 575-83$.

10. Cant AJ. Viral infections in the immunocompromised. In: Proceedings of the 26th annual meeting of the European society for pediatric infections diseases. ESPID; 2008 May 13-17; Graz, Austria. 2008. p. 36.

11. Toth K, Hussein ITM, Tollefson AE, Ying B, Spencer JF, Eagar J, James SH, Prichard MN, Wold WSM, Bowlin TL. Filociclovir is a potent in vitro and in vivo inhibitor of human adenovi- 
ruses. Antimicrob Agents Chemother. Manuscript Posted Online 17 August 2020 doi:10.1128/ AAC.01299-20

12. Nosach LN. [Adenovirus infection and prospects for its treatment]. Practical Medicine. 2011; 13(1): 66-72. Ukrainian.

13. Strand M. The discovery of antiviral compounds targeting adenovirus and herpes simplex virus. Assessment of synthetic compounds and natural products: Doctoral thesis/Department of Clinical Microbiology, Virology. Umeå University. Umeå. 2014. 104 p.

14. Mosmann T. Rapid colorimetric assay for cellular growth and surviral: application to proliferation and cytotoxicity assays. J Immunol Methods. 1983; 65:55-63.

15. Kodama E, Shigeta S, Suzuki T, De Clerq E. Application of gastric cancer cell line (MKN-28) for anti-adenovirus screening using the MTT method. Antiviral Research. 1996; 31:159-64.

16. Povnitsa OYu, Biliavska LO, Pankivska YuB, et al. [Anti-adenoviral activity of Neoflazid in vitro]. Mikrobiol Z. 2018; 80:98-109. Ukrainian.

17. Mary Miu Yee Waye, Chor Wing Sing. Anti-Viral Drugs for Human Adenoviruses. Pharmaceuticals. 2010; 3:3343-3354. doi: $10.3390 /$ ph3103343

18. Shcherbinskaya AM, Dyachenko NS, Rybalko SL, Nosach LM, Dyadyun ST, Vrynchanu NO. [Preclinical studies of drugs. Guidelines]. Kiev. 2001; 371-395. Russian.

19. Gordon YJ, Romanowski E, Araullo-Cruz T, De Clercq E. Pretreatment with topical 0.1\% (S) -1(3-hydroxy-2-phosphonylmethoxypropyl) cytosine inhibits adenovirus type 5 replication in the New Zealand rabbit ocular model. Cornea. 1992; 11(6):529-533.

20. Uchio E, Inoue H, Fuchigami A, Kadonosono K. Anti-adenoviral effect of interferon- $\beta$ and interferon- $\gamma$ in serotypes that cause acute keratoconjunctivitis. Clin Experiment Ophthalmol. 2011; 39 (4):358-63.
21. Nwanegbo EC, Romanowski EG, Gordon YJ, Gambotto A. Efficacy of topical immunoglobulins against experimental adenoviral ocular infection. Invest Ophthalmol Vis Sci. 2007; 48(9):4171-6.

22. Sologub TV, Golobokov GS, Tsvetkov VV, Tokin II. [Interferon-gamma in the treatment of influenza and other respiratory viral infections]. Medical advice. 2015; 7:54-8. Russian.

23. Savenkova MS. [Treatment of viral infections: the problem of choosing effective antiviral drugs]. Pediatrics. 2012; 91(6):70-7. Russian.

24. Samsygina GA. [Modern treatment of acute respiratory diseases in children]. Pediatrics. 2013; 92 (3):38-42. Russian.

25. Narovlyansky AN, Ershov FI, Ginsburg AL. [Interferons: promising areas of research]. Immunology. 2013; 3:168-172. Russian.

26. Dzyublyk IV, Dyachenko NS, Rybalko SL, Shcherbinskaya AM, Nosach LM, Voronenko SG, Poroghnitsky VG. [Manual on chemotherapy of viral infections. Educational and methodical manual for doctors]. Kyiv Medical Academy of Postgraduate Education of the Ministry of Health of Ukraine. Kyiv; 2004. Ukrainian.

27. Kitajewski J, Schneider RJ, Safer B, et al. Adenovirus VAI RNA antagonizes of interferon by preventing activation of the interferon-induced eIF2 alpha kinase. Cell. 1986; 45(2):195-200.

28. Yushchuk ND, Khadartsev OS. [Prevention of influenza and acute respiratory viral infections, taking into account the peculiarities of their epidemic process]. Infectious diseases.2018; 7(2):44-51. Ukrainian.

29. Malyshev NA, Lvov NI, Maltsev OV. [Evaluation of the effectiveness and safety of complex therapy of acute respiratory diseases of adenoviral etiology in young people]. The attending physician.2018; 5:89-94. Russian.

30. Kuznetsov SV, Kopeichenko TS. [Interferonotherapy of acute respiratory viral infections in children. Journal of current infectology]. 2016; 1(10):48-50. Russian. 
31. Besh LV. [Evaluation of the effectiveness of interferon drugs in the treatment of acute respiratory viral infections in children who are often ill]. Health of Ukraine. 2014; 9:12-3. Ukrainian.

32. Kramarev SO, Vygovskaya OV. [Rationale for the use of interferon drugs in acute respiratory infections in children]. Clinical immunology, al- lergology, infectology. 2007; 5(10). https: //kiai. com.ua/ua-archive-issue-10. Ukrainian.

33. Krasnov VV. [Influenza and SARS: the use of recombinant interferon for the treatment and prevention of children]. Pediatric Practice. 2019; 1:24-9. Ukrainian.

Received 8.09.2020 